\title{
DISFEMISME PADA WACANA LINGKUNGAN: SEBUAH KAJIAN EKOLINGUISTIK KRITIS DALAM MEDIA MASSA DI INDONESIA
}

\author{
(DYSPHEMISM USED IN ENVIRONMENTAL DISCOURSE: AN ECO- \\ CRITICAL DISCOURSE ANALYSIS ON INDONESIAN MASS MEDIA)
}

\author{
Elisa Nurul Laili \\ Jalan RayaGenengan RT.01 RW.01 Genengan \\ Doko, Blitar, Jawa Timur, Indonesia 66186 \\ Pos-el: elisa_nurullaili@yahoo.co.id
}

Diterima: 31 Agustus 2013; Direvisi: 5 Desember 2013; Disetujui: 6 Desember 2013

\begin{abstract}
Mass media uses various language devices to wrap constructive and destructive ideology concerning the ecology, such as euphemism and dysphemism. This research identifies language problems of environmental discourses in Indonesian mass media concerning to dysphemism. This is qualitative descriptive research. The data were collected from some magazines: Gatra, Tempo, Trust, harian Kompas, Kabar Indonesia, Media Indonesia, Suara Merdeka, and Surabaya Pagi, portal Antara, Vivanews, Detiknews, Metronews, and Okezone by applying obervation method continued with recording method. The data taken were limitted to polution, and environment reservation. The data were analyzed by using distributional and identical technique continued with subtitution and pharafrasing technique. There are four dysphemism units of expression used by Indonesian mass media on environmental discourse, namely are words, phrases, clauses, and sentences. The unit of expression in form of words is root words, derivational words, and plural words.The dysphemism unit of expression in form of derivational words is nouns, verbs, and adjectives. The unit of expression in form of phrase is noun phrase, adjective phrase, and phrasal verbs. The dysphemism found are referring to human, plants, animals, soil, nuclear, poisinous materials, trash and waste, polution, habitat destruction, species extinction, and taboo. There are tweleve fucntions of dysphemism unit of expression, namely are (1) expressing hatred or abomination, (2) criticizing, (3) allusion, (4) blaming or accusing, (5) whinning, (6) informing, (7) humiliating, mocking or deepening humiliation, (8) warning, (9) disagreement, (10) dislikeness, (11) exagerrating, and (12) proofing.
\end{abstract}

Keywords: dysphemism, environmental discourse, eco-critical discourse analysis

\begin{abstract}
Abstrak
Media massa menggunakan berbagai piranti bahasa untuk mengemas ideologi konstruktif dan destruktif terkait dengan lingkungan, misalnya eufemisme dan disfemisme. Penelitian ini berusaha mengkaji permasalahan kebahasaan yang terdapat dalam wacana lingkungan dalam media massa di Indonesia, yakni mengenai disfemisme. Penelitian ini merupakan penelitian deskriptif kualitatif. Data dikumpulkan dari majalah Gatra, Tempo, Trust, harian Kompas, Kabar Indonesia, Media Indonesia, Suara Merdeka, dan Surabaya Pagi, portal Antara, Vivanews, Detiknews, Metronews, dan Okezone menggunakan metode simak, dengan teknik lanjutan berupa teknik catat. Namun, data tersebut dibatasi hanya seputar permasalahan tentang polusi, pencemaran, dan reservasi lingkungan. Analisis data dilakukan menggunakan metode agih dan metode padan dengan teknik lanjutan berupa teknik substitusi dan parafrase. Bentuk satuan ekspresi disfemisme yang digunakan oleh media massa di Indonesia pada wacana lingkungan ada empat macam, yaitu kata, frase, klausa, dan kalimat. Satuan ekspresi yang berbentuk kata, yaitu berupa kata dasar, kata turunan dan kata majemuk.Satuan ekspresi disfemisme berbentuk kata turunan, yaitu kata turunan berkategori nomina, verba, dan ajektiva.
\end{abstract}


Satuan ekspresi disfemisme yang berbentuk frase, yaitu frase nomina, frase ajektiva, dan frase verba. Referensi disfemisme yang ditemukan berkaitan dengan manusia, tumbuhan, binatang, tanah, nuklir dan material beracun, sampah dan limbah, polusi, perusakan habitat alami, kepunahan spesies, dan tabu. Fungsi-fungsi satuan ekspresi disfemisme ada dua belas macam, yaitu (1) mengungkapkan kemarahan atau kejengkelan, (2) mengkritik, (3) menyindir, (4) menuduh atau menyalahkan, (5) mengeluh, (6) menyampaikan informasi, (7) menghina, mengejek atau mempertajam penghinaan, (8) memperingatkan, (9) menunjukkan ketidaksetujuan, (10) menunjukkan rasa tidak suka, (11) melebihlebihkan, dan (12) menunjukkan bukti.

Kata kunci: disfemisme,wacana lingkungan, ekolinguistik kritis

\section{Pendahuluan}

Isu tentang lingkungan merupakan permasalahan yang aktual dan menarik untuk diperbincangkan. Ilmu linguistik dewasa ini juga mengkaji permasalahan kebahasaan yang mulai berubah seiring dengan perubahan lingkungan. Permasalahan kebahasaan yang berkaitan dengan perubahan lingkungan ini dikaji dalam ilmu ekolinguistik dan ekolinguistik kritis. Penelitian ini berusaha mengkaji permasalahan kebahasaan yang terdapat pada wacana lingkungan dalam media massa di Indonesia, yakni mengenai disfemisme. Karena itulah, penelitian ini termasuk ke dalam ranah ekolinguistik kritis. Penelitian ini bertujuan untuk mengetahui bentukbentuk, referensi, tipe-tipe, dan fungsifungsi satuan ekspresi disfemisme pada wacana lingkungan dalam media massa di Indonesia.

Ekolinguistik kritis mempersoalkan teks-teks yang berkenaan dengan lingkungan. Teks-teks tersebut diciptakan oleh media massa sehingga terciptalah realitas yang mengkonstruksi masyarakat tentang lingkungan. Media massa mempengaruhi kognisi pembaca atau masyarakat untuk berpartisipasi melestarikan lingkungan. Namun ada pula wacana yang diciptakan oleh media sarat akan muatan politis yang konstruktif dan destruktif.

Wacana yang bermuatan politis ini tidak terlepas dari peran beberapa tokoh bangsa Indonesia yang memiliki andil terhadap lingkungan. Beberapa figur publik tersebut ada kalanya berperan dalam melestarikan lingkungan, dan sebaliknya, ada pula yang berperan dalam merusak lingkungan. Media massa menggiring pembaca untuk ikut mengetahui realitas tersebut. Media massa menggunakan berbagai piranti bahasa untuk mengemas ideologi konstruktif dan destruktif terkait dengan lingkungan, misalnya eufemisme dan disfemisme.

Disfemismedalam wacana lingkungan lebih bervariasi dibandingkan dalam ranah sosiolinguistik yang berkaitan erat dengan konsep tabu. Disfemisme dalam wacana lingkungan juga memiliki tujuan politis ideologis. Dalam media massa luar negeri, penggunaan disfemisme pada wacana lingkungan jarang dilakukan. Jurnalis lebih memilih menggunakan eufemisme dibandingkan disfemisme. Namun, lain halnya dengan media massa di Indonesia, peneliti menemukan beberapa disfemisme yang digunakan dalam media massa dalam wacana lingkungan. Sejalan dengan hal ini, Ali Masri dalam Kasmansyah (via Khairah, 2013:1) menyebutkan bahwa bahasa Indonesia yang digunakan dalam media massa cenderung lebih banyak menggunakan kata atau bentuk bahasa pengasaran (disfemisme) yang merupakan kebalikan dari bentuk eufemisme (penghalusan).

Penggunaan disfemisme ini tentunya memiliki beberapa maksud dan tujuan tertentu. Selain itu, penggunaan disfemisme dalam wacana lingkungan juga berpengaruh terhadap kognisi penuturnya, yang dalam hal 
ini adalah para pembaca serta pemerhati masalah lingkungan. Berawal dari hal tersebut, peneliti tertarik untuk mengkaji disfemisme yang berkaitan dengan wacana lingkungan, terutama yang terdapat dalam media massa di Indonesia.

\section{Kerangka Teori}

Ekologi bahasa menurut Haugen (Haugen dalam Fill dan Muhlhausler, 2001:57) adalah studi tentang interaksi antarbahasa yang ada dengan lingkungannya. Fill (dalam Fill dan Muhlhausler, 2001:51) mendefinisikan ekolinguistik sebagai studi yang lebih luas lingkupnya dalam mempelajari sintaksis, semantik, dan pragmatik. Karena itulah, dibutuhkan beberapa teori baru yang inovatif untuk menginvestigasi ide-ide tersebut secara empiris.

Crystal (2008:161-162) mendefinisikan ekolinguistik adalah sebuah studi yang merefleksikan sifat ekologi dalam studi biologis, yang mana interaksi antara bahasa dan lingkungan kultural dilihat sebagai inti: disebut pula dengan ekologi bahasa, ekologi linguistik dan kadang-kadang linguistik hijau.

Alexander dan Stibbe (2011) mendefinisikan ekolinguistik sebagai studi tentang dampak penggunaan bahasa dalam keberlangsungan hidup yang menjembatani hubungan antara manusia, organisme lain, dan lingkungan fisik yang secara normatif berorientasi pada pelestarian hubunganhubungan yang berkelanjutan dalam kehidupan. Dengan kata lain, ekolinguistik berkaitan erat dengan bagaimana bahasa berperan untuk membentuk, memelihara, mempengaruhi, atau merusak hubungan antara manusia, kondisi kehidupan dan lingkungannya. Ekolinguistik berkembang sebagai akibat dari perkembangan ekologi manusia yang berkaitan dengan berbagai sistem (sistem ekonomi, sosial, agama, budaya. linguistik dan ekosistem) yang saling bergantung dan berhubungan satu sama lain (Stibbe, 2010:1).

Analisis Wacana Kritis menurut Fairclough dan Wodak dalam van Dijk (1997:55) memandang wacana (penggunaan bahasa dalam tuturan dan tulisan) sebagai sebuah bentuk praktik sosial dan menjelaskan wacana sebagai praktik sosial menyiratkan suatu hubungan dialektik antara peristiwa diskursif tertentu dengan situasisituasinya, institusi-institusi, dan struktur sosial yang mewadahinya. Suatu hubungan dialektik merupakan sebuah hubungan dua jalur: peristiwa diskursif dibentuk oleh situasi, institusi dan struktur sosial, tapi juga membentuk ketiganya.

AWK dikembangkan Fairclough berdasarkan asumsi linguistik fungsionalsistemik yang dikembangkan oleh Halliday, bahwa bahasa dalam teks (wacana) selalu mengemban tiga fungsi sekaligus: secara ideasional merepresentasikan pengalaman dan dunia, secara interpersonal membentuk interaksi sosial antara partisipan dan wacana, serta secara tekstual mengaitkan teks dengan konteks situasional (periksa Fairclough, 1995:6). AWK juga dikembangkan Wodak dan van Dijk yang dipengaruhi model perencanaan teks kognitif (Subagyo, 2009:143).

Kajian ekolinguistik baru-baru ini juga dipengaruhi oleh AWK. Ekolinguistik mengkaji wacana tentang lingkungan, dan bermacam bentuk wacana yang ideologinya menyangkut manusia dan lingkungan. Wacana lingkungan dengan semua perwujudannya (teks lisan, teks tertulis, gambar dan internet) ini disebut greenspeak atau wacana hijau (Harre dalam Fill, 2011:8). Analisis wacana eko-kritis tidak sebatas menganalisis bahasa secara mikrostruktur saja, tetapi juga membahas permasalahan makrostruktur bahasa seperti gaya bahasa, eufemisme, disfemisme dan lain-lain. 
Wacana lingkungan dikonstruksi untuk beberapa tujuan dan maksud tertentu. Adakalanya wacana tersebut digunakan untuk kampanye atau sosialisasi pelestarian lingkungan hidup, serta kritik terhadap oknum-oknum yang berperan dalam kerusakan lingkungan.Wacana ini lebih banyak dikemas dengan istilah-istilah yang eufemistis. Selain eufemisme, dalam media massa Indonesia juga ditemukan penggunaan ekspresi disfemistis. Hal ini sangat berbeda dengan media massa yang terdapat di luar negeri, yang lebih memilih untuk menggunakan ekspresi eufemistis saja dengan beberapa pertimbangan politis.

Ekolinguistik kritis dibagi menjadi dua bagian, yaitu bagian yang mengkritisi sistem (tata bahasa/grammar) dan bagian yang mengkritisi teks. Beberapa peneliti sistem atau tata bahasa di antaranya adalah M.A.K. Halliday, Andrew Goatly dan Mary Schleppergrell. Sedangkan beberapa peneliti teks atau artikel eko-kritis di antaranya adalah Harre, Brockmeier dan Muhlhausler. Teks yang diteliti tersebut antara lain adalah pidato politik, iklan lingkungan (green ads), artikel-artikel tentang lingkungan, dan sebagainya (Fill dan Muhlhausler, 2001:67). Analisis eko-kritis sendiri meliputi penggunaan kosakata, diksi, eufemisme, disfemisme, dan lain-lain.

Trampe dalam Fill dan Muhlhausler (2001:238-239) menyatakan bahwa wacana lingkungan dalam media massa biasanya mengandung hal-hal sebagai berikut: (1) Reifikasi, yaitu memperlakukan makhluk hidup sebagai objek yang bernilai ekonomis, berkaitan dengan teknologi dan ideologis. Misalnya makhluk hidup atau sumber daya dapat diproduksi, dioptimalkan, dikelola, dan digunakan (dimanfaatkan); (2) Menyembunyikan fakta, yaitu penggunaan eufemisme untuk menggantikan beberapa kata atau istilah yang dihindari. Misalnya, yang berkaitan dengan kematian, penghancuran atau perusakan, pembasmian atau pemusnahan, dan racun; (3) Menyatakan kebencian atau perlawanan terhadap pihak-pihak yang merusak lahan tradisional atau lahan adat; (4) Menciptakan slogan dan elemen yang menyampaikan ide dan gagasan yang digunakan untuk membuat proses perusakan lingkungan dan kebudayaan yang dilakukan oleh sekelompok orang tampak seolah sesuai dan sejalan dengan hukum alam.

Schultz (Fill dan Muhlhausler, 2001:109-110) menyatakan bahwa terdapat tiga piranti linguistik atau kebahasaan yang sering digunakan dalam teks yang berkaitan dengan komersialisasi lingkungan. Pertama, penggunaan kata-kata netral yang mempunyai konotasi pujian atau cenderung memihak terhadap eksploitasi, tapi realitas yang diwakili kata tersebut sangat berbeda. Misalnya, penggunaan kata atau istilah ecologically sustainable development, fertilizer dan human resources. Kedua, piranti yang sering digunakan, yaitu penggunaan eufemisme (penyebutan benda atau sesuatu hal yang tidak menyenangkan menjadi lebih sopan). Misalnya, penggunaan istilah clearing, harvest, greenhouse effect dan global warming. Ketiga, piranti yang jarang digunakan tapi sangat kuat efeknya bila digunakan, yaitu penggunaan istilah-istilah peyoratif atau disfemisme (penyebutan benda atau sesuatu hal dengan konotasi yang lebih negatif). Misalnya, penggunaan kata atau istilah earthworm food dan animals' homes untuk menyebut humus.

Garner (2000) menyatakan bahwa disfemisme adalah mengganti kata-kata atau frase yang bermakna netral atau positif dengan kata-kata yang tidak menyenangkan. Disfemisme merupakan kebalikan dari eufemisme. Disfemisme digunakan untuk menyerang petutur atau pendengarnya.

Allan dan Burridge (1991:26) mendefinisikan disfemisme adalah ekspresiekspresi dengan konotasi yang menyakitkan 
bagi yang diajak bicara maupun yang mendengarkan, sehingga ungkapan tersebut biasanya diganti dengan ekspresi-ekspresi yang lebih netral atau lebih eufemistis. Disfemisme digunakan untuk membicarakan lawan, sesuatu yang diharapkan dapat menunjukkan ketidaksukaan, serta sesuatu yang diharapkan lebih menghina, meremehkan atau merendahkan lawan. Allan dan Burridge (2006:31) juga menambahkan bahwa disfemisme adalah kata atau frase yang berkonotasi menyakitkan atau mengganggu baik orang yang diajak bicara dan/atau orang yang dibicarakan serta orang yang mendengarkan ungkapan tersebut.

Referensi disfemisme yang digunakan dalam wacana lingkungan agak berbeda dengan referensi disfemisme yang biasa digunakan dalam ranah sosiolinguistik sebagaimana yang telah diajukan oleh Allan dan Burridge. Trampe (dalam Fill dan Muhlhausler, 2001:233-239) menyebutkan beberapa referensi eufemisme dalam wacana lingkungan yang terdapat dalam media massa di Jerman, antara lain berkaitan dengan hal-hal sebagai berikut: permasalahan mengenai sampah, limbah, material beracun, dan polusi, (2) perusakan habitat alami dan kepunahan beberapa spesies, (3) energi nuklir, (4) tumbuhan atau tanaman, (5) hewan, dan (6) bentang daratan dan tanah.

\section{Metode Penelitian}

Penelitian ini merupakan penelitian deskriptif kualitatif. Data dikumpulkan dengan metode simak, dengan teknik lanjutan berupa teknik catat. Data dikumpulkan dari beberapa media massa berbahasa Indonesia, baik cetak (majalah dan surat kabar) maupun elektronik (portal berita dari media internet), yang berisi tentang wacana lingkungan. Data dari media cetak diperoleh dari majalah dan surat kabar, yaitu majalah Gatra, majalah Tempo, majalah Trust, harian Kompas, harian Kabar Indonesia, harian Media Indonesia, harian Suara Merdeka, dan harian Surabaya Pagi. Sedangkan data dari media massa internet diperoleh dari beberapa portal, yakni Antara, Vivanews, Detiknews, Metronews, dan Okezone, tapi data tersebut dibatasi hanya seputar permasalahan tentang polusi, pencemaran, dan reservasi lingkungan. Kemudian, data dianalisis dengan metode agih dan metode padan dengan teknik lanjutan berupa teknik substitusi dan parafrase. Lalu, hasil analisis data disajikan secara informal. Penelitian ini menggunakan kerangka teori Allan dan Burridge dan Trampe sebagai pisau analisis data. Namun, juga digunakan beberapa teori yang relevan agar hasil analisis lebih mendalam dan komprehensif.

\section{Pembahasan}

\subsection{Bentuk-bentuk Satuan Ekspresi Disfemisme}

Bentuk satuan ekspresi disfemisme yang digunakan oleh media massa di Indonesia pada wacana lingkungan ada empat macam. Satuan ekspresi tersebut berbentuk kata, frase, klausa, dan kalimat. Adapun satuan ekspresi yang berbentuk kata, terbagi menjadi tiga macam, yaitu kata dasar, kata turunan dan kata majemuk. Satuan ekspresi disfemisme berupa kata turunan terbagi menjadi tiga, yakni kata turunan berkategori nomina, verba dan ajektiva. Satuan ekspresi disfemisme yang berupa frase terbagi menjadi tiga, yaitu frase nomina, frase ajektiva, dan frase verba.

\subsubsection{Satuan Ekspresi Disfemisme Berupa Kata}

Satuan ekspresi disfemisme yang berupa kata dibagi menjadi tiga macam, yaitu kata dasar, kata turunan dan kata majemuk. Pembahasannya adalah sebagai berikut. 


\subsubsection{Satuan Ekspresi Disfemisme Berupa Kata Dasar}

Satuan ekspresi disfemisme yang digunakan oleh media massa Indonesia dalam wacana lingkungan cukup bervariasi. Adapun kategori satuan ekspresi disfemisme yang berupa kata dasar meliputi kategori nomina, verba, dan ajektiva.

\subsection{Kategori Nomina}

Disfemisme berupa kata dasar berkategori nomina yang terdapat dalam media massa Indonesia cukup bervariasi. Masing-masing berasal dari bahasa Indonesia asli, bahasa daerah, nama tempat, dan bahasa asing yang diadaptasi atau diadopsi ke dalam bahasa Indonesia. Misalnya kata momok untuk menggantikan kata gangguan, kata sindikat untuk menggantikan kata perkumpulan dan kata Bhopal untuk menggantikan istilah tragedi kematian karena polusi.

\subsection{Kategori Verba}

Disfemisme berupa kata dasar berkategori verba yang terdapat dalam media massa Indonesia berasal dari bahasa Indonesia asli dan bahasa daerah. Misalnya, kata tewas untuk menggantikan istilah meninggal dunia dan kata ngendon untuk menggantikan istilah dibiarkan saja.

\subsection{Kategori Ajektiva}

Disfemisme berupa kata dasar berkategori ajektiva yang terdapat dalam media massa Indonesia cukup bervariasi. Ajektiva dasar tersebut berasal dari bahasa Indonesia asli, bahasa daerah dan bahasa asing yang diadaptasi ke dalam bahasa Indonesia. Misalnya, kata nakal untuk menggantikan istilah susahdiperingatkan, kata tekor untuk menggantikan kata kekurangan dan kata bubrah untuk menggantikan kata rusak atau hancur.

\subsubsection{Satuan Ekspresi Disfemisme Berupa Kata Turunan}

Selain bentuk ekspresi yang berupa kata dasar, terdapat pula satuan ekspresi disfemisme yang berupa bentuk turunan. Bentuk turunan merupakan kata yang mengalami proses afiksasi, reduplikasi dan pemajemukan. Satuan ekspresi yang mengalami proses pembubuhan afiks antara lain sebagai berikut.

\subsection{Bentuk Turunan Kategori Nomina}

Satuan ekspresi disfemisme berupa kata berafiks kategori nomina yang terdapat dalam media massa Indonesia berasal dari bahasa Indonesia asli, bahasa daerah, dan bahasa asing yang diadaptasi atau diadopsi ke dalam bahasa Indonesia. Misalnya, kata penggurunan untuk menggantikan istilah kekeringan, kata penyerobotan untuk menggantikan kata pengambilalihan dan perselingkuhan untuk menggantikan istilah kerjasama.

\subsection{Bentuk Turunan Kategori Verba}

Satuan ekspresi disfemisme berupa kata berafiks kategori verba yang terdapat dalam media massa Indonesia berasal dari bahasa Indonesia asli, bahasa daerah, dan bahasa asing yang diadaptasi atau diadopsi ke dalam bahasa Indonesia. Misalnya, kata memangsa untuk menggantikan istilah mengambil alih, kata dilahap untuk mengggantikan istilah dimanfaatkan dan kata di-Gayus-kan untuk menggantikan istilah dikorupsi.

\subsection{Bentuk Turunan Kategori Ajektiva}

Satuan ekspresi disfemisme berupa kata berafiks kategori ajektiva yang terdapat dalam media massa Indonesia berasal dari bahasa Indonesia asli, bahasa daerah, dan bahasa asing yang diadaptasi atau diadopsi ke dalam bahasa Indonesia. Misalnya, istilah 
menggunung untuk menggantikan istilah menumpuk dan terpinggirkan untuk mengantikan istilah belum mendapatkan hak dan kewajiban.

\subsubsection{Satuan Ekspresi Disfemisme Berupa Kata Majemuk}

Satuan ekspresi disfemisme berupa kata majemuk yang terdapat pada wacana lingkungan dalam media massa di Indonesia ada yang berasal dari bahasa Indonesia asli dan bahasa asing. Kata majemuk tersebut juga ada yang mengalami afiksasi. Misalnya, koboi karbon untuk menggantikan istilah pedagang karbon, dan istilah melek karbon untuk menggantikan istilah sadar lingkungan.

\subsubsection{Satuan Ekspresi Disfemisme Berupa Frase}

Satuan ekspresi disfemisme berupa frase yang terdapat pada wacana lingkungan dalam media massa di Indonesia berupa frase nomina, frase ajektiva, dan frase idiomatis.

\subsubsection{Satuan Ekspresi Disfemisme Berupa Frase Nomina}

Satuan ekspresi disfemisme berupa frase nomina yang terdapat pada wacana lingkungan dalam media massa di Indonesia memiliki konstruksi yang bervariasi. Misalnya, frase kota hantu untuk menggantikan istilah kota yang tak terlihat aktivitasnya, lumpur Lapindo untuk menggantikan istilah lumpur Sidoarjo dan istilah zero sum game untuk menggantikan istilah satu untung satu rugi.

\subsubsection{Satuan Ekspresi Disfemisme Berupa Frase Ajektiva}

Satuan ekspresi disfemisme berupa frase ajektiva yang terdapat pada wacana lingkungan dalam media massa di Indonesia tidak banyak memiliki konstruksi yang bervariasi. Misalnya, frase lapar akan energy untuk menggantikan istilah selalu berusaha menguasai sumber energi dan sumber daya alam.

\subsubsection{Satuan Ekspresi Disfemisme Berupa Frase Verba}

Satuan ekspresi eufemisme berupa frase idiomatis yang terdapat pada wacana lingkungan dalam media massa di Indonesia cukup bervariasi. Misalnya, memotong kepala untuk menggantikan frase membunuh, frase tutup mulut untuk menggantikan istilah berdiam diri tanpa melakukan tindakan apapun.

\subsubsection{Satuan Ekspresi Disfemisme Berupa Klausa}

Selain kata dan frase, satuan ekspresi disfemisme yang digunakan pada wacana lingkungan dalam media massa Indonesia yaitu klausa. Satuan ekspresi disfemisme berupa klausa yang ditemukan dalam data dapat menempati posisi sebagai klausa inti maupun klausa bawahan. Misalnya, dalam kalimat "Tapi kalau kelakuan orang Indonesia seringkali mengail ikan di air keruh, maka hak publik akan terus dikorupsi, termasuk dana yang telah dikeluarkan oleh Lapindo", kalimat "Mengajak negara-negara berseteru duduk bersama seperti merukunkan macan dan gajah", dan kalimat "Airnya cokelat pekat terbalut oleh lumpur dan limbah industri."

\subsubsection{Satuan Ekspresi Disfemisme Berupa Kalimat}

Selain kata, frase, dan klausa, satuan ekspresi disfemisme yang digunakan pada wacana lingkungan dalam media massa Indonesia yaitu kalimat. Ekspresi disfemisme berupa kalimat yang ditemukan dalam data cukup banyak dan bervariasi. Kalimat-kalimat tersebut ada yang secara langsung menunjukkan disfemisme, dan ada pula yang bersifat perbandingan serta mengandung makna kiasan. Misalnya, 
kalimat "Bukan untung, malah buntung", kalimat "Lapindo yang berbuat, mari kita ikut kualat", dan kalimat "Setelah lima tahun lalu menerima predikat sebagai perusahaan pencemar dan perusak lingkungan hidup, PT Lapindo Brantas Incorporated, kali ini kembali akan menerima "Pagebluk Award"."

\subsection{Referensi Satuan Ekspresi Disfemisme}

Referensi disfemisme pada wacana lingkungan digunakan untuk menyampaikan hal-hal yang berkaitan dengan manusia, tumbuhan, binatang, tanah, nuklir dan material beracun, sampah dan limbah, polusi, perusakan habitat alami, kepunahan spesies dan tabu. Masing-masing merujuk kepada segala hal yang berkenaan dengan sifat, keadaan, aktivitas, profesi, benda, tempat, peristiwa, dan -ist difemisme. Sedangkan yang merujuk pada hal-hal tabu, antara lain tentang aktivitas SDM, makhluk halus, kematian, dan kriminalitas. Berikut adalah referen disfemisme yang ditemukan dalam data.

\subsubsection{Referen Disfemisme yang Berhubungan dengan Manusia}

Satuan ekspresi yang berhubungan dengan manusia meliputi sifat, keadaan, aktivitas, profesi, dan -ist disfemisme. Misalnya, laparakan energi untuk menggantikan mengeksplorasi energi, petualang untuk menggantikan pemerintah, mencuri untuk menggantikan mengkorupsi dan gerakan anti-Kyoto untuk menggantikan negara industri maju.

\subsubsection{Referen Disfemisme yang Berhubungan dengan Tumbuhan}

Satuan ekspresi yang berhubungan dengan tumbuhan meliputi profesi dan aktivitas yang berkaitan dengan tumbuhan. Misalnya, kata dilahap untuk menggantikan dimanfaatkan, dan cukong kayu untuk pengusaha karbon.

\subsubsection{Referen Disfemisme yang Berhubungan dengan Binatang}

Satuan ekspresi yang berhubungan dengan binatang meliputi aktivitas, benda, serta membandingkan manusia dengan binatang yang memiliki persamaan sifat. Misalnya, macan kertas untuk menggantikan seribu janji namun nihil aksi, bulan-bulanan untuk menggantikan korban perburuan, dan mencekoki untuk menggantikan kata mengobati.

\subsubsection{Referen Disfemisme yang Berhubungan dengan Tanah}

Satuan ekspresi yang berhubungan dengan tanah meliputi keadaan, sifat dan aktivitas. Misalnya, kata lahan mati untuk menggantikan lahan tidak subur atau produktif, dan penggurunan untuk menggantikan kekeringan.

\subsubsection{Referen Disfemisme yang Berhubungan dengan Nuklir dan Material Beracun}

Satuan ekspresi yang berhubungan dengan nuklir dan material beracun meliputi peristiwa, aktivitas, keadaan dan benda. Misalnya, bencana radiasi nuklir untuk menggantikan bencana Chernobyl, menyurukkan untuk menggantikan kata menyusupkan, ketergantungan terhadap energi nuklir untuk menggantikan pemanfaatan energi nuklir, dan gas beracun amonia untuk menggantikan senyawa amonia.

\subsubsection{Referen Disfemisme yang Berhubungan dengan Sampah dan Limbah}

Satuan ekspresi yang berhubungan dengan sampah dan limbah meliputi aktivitas, keadaan, tempat, dan benda. Misalnya, menggelontorkan untuk menggantikan kata membuang, menggunung untuk menggantikan kata menumpuk, lumbung sampah untuk menggantikan kata 
tempat sampah, dan ranjau sampah untuk menggantikan tumpukan sampah.

\subsubsection{Referen Disfemisme yang Berhubungan dengan Polusi}

Satuan ekspresi yang berhubungan dengan polusi meliputi keadaan dan peristiwa. Misalnya, istilah terbalut oleh lumpur dan limbah industri untuk menggantikan kata tercemar dan kata Bhopal untuk menggantikan tragedi kematian akibat pencemaran.

\subsubsection{Referen Disfemisme yang} Berhubungan dengan Perusakan Habitat Alami

Satuan ekspresi yang berhubungan dengan perusakan habitat alami meliputi aktivitas dan sifat. Misalnya, penggundulan hutan, penjarahan hutan, dan paling rakus memangsa hutan untuk menggantikan illegal logging.

\subsubsection{Referen Disfemisme yang} Berhubungan dengan Kepunahan Spesies

Satuan ekspresi yang berhubungan dengan kepunahan spesies meliputi tempat dan aktivitas. Misalnya, kota hantu untuk kota tak berpenduduk, pembasmian hama untuk menggantikan perburuan orangutan, dan dicincang untuk dibunuh.

\subsubsection{Referen Disfemisme yang Berhubungan dengan Tabu}

Satuan ekspresi yang berhubungan dengan tabu meliputi makhluk halus, binatang dan kriminalitas. Misalnya, kentut untuk menggantikan kata kebocoran, momok untuk menggantikan istilah pengganggu, membunuh untuk menggantikan istilah menyebabkan penyakit yang memicu kematian, di-Gayus-kan untuk menggantikan kata dikorupsi atau digelapkan dan sindikat untuk menggantikan kata perkumpulan.

\subsection{Tipe-tipe Satuan Ekspresi Disfemisme}

Tipe-tipe satuan ekspresi disfemisme yang terdapat pada wacana lingkungan dalam media massa di Indonesia ada sebelas macam, yaitu penggunaan ekspresi figuratif (misalnya penggundulan hutan untuk menggantikan illegal logging), pemodelan kembali (hopelesshagen untuk menggantikan kekecewaan pada putusan konferensi Copenhagen), sirkumlokusi (misalnya terperosok dalam alam pikiran yang sudah didesain untuk menggantikan istilah tertipu), metonimia (misalnya Bhopal untuk tragedi kematian akibat pencemaran dan di-Gayuskan untuk menggantikan kata dikorupsi), sinestesia (pengalaman pahit untuk menggantikan kejadian bencana akibat penambangan dan dimakan untuk menggantikan dialih manfaatkan), satu kata untuk menggantikan kata yang lain (tewas untuk menggantikan kata meninggal dan tekor untuk menggantikan kata kekurangan), synecdoche totem pro parte (misalnya kutukan Copenhagen untuk menggantikan hasil putusan konferensi Copenhagen), hiperbola (misalnya ranjau sampah untuk menggantikan tumpukan sampah), penggunaan istilah teknis (misalnya kata sindikat untuk perkumpulan), penggunaan istilah kolokial (misalnya istilah molor untuk menggantikan tidak tepat waktu), dan pinjaman dari bahasa lain (climate mafia untuk menggantikan badan pengawas iklim dunia atau IPCC dan kata bubrah untuk menggantikan kata rusak).

\subsection{Fungsi-fungsi Satuan Ekspresi Disfemisme}

Fungsi-fungsi satuan ekspresi disfemisme yang terdapat pada wacana lingkungan dalam media massa di Indonesia ada dua belas macam, yaitu: (1) mengungkapkan kemarahan atau kejengkelan, (2) mengkritik, (3) menyindir, (4) menuduh atau menyalahkan, (5) mengeluh, (6) menyampaikan informasi, (7) 
menghina, mengejek atau mempertajam penghinaan, (8) memperingatkan, (9) menunjukkan ketidaksetujuan, (10) menunjukkan rasa tidak suka, (11) melebihlebihkan, dan (12) menunjukkan bukti.

\section{Penutup}

Disfemisme cukup banyak digunakan dalam wacana lingkungan media massa Indonesia. Disfemisme merupakan piranti kebahasaan yang banyak digunakan oleh jurnalis di Indonesia, seperti halnya penggunaan eufemisme. Disfemisme, sebagaimana eufemisme, juga merupakan bentuk praktik wacana yang membentuk realitas ciptaan jurnalis.Realitas tersebut dapat mempengaruhi kognisi pembacanya. Mengingat pembaca wacana tersebut beragam, baik dari segi usia, jenis kelamin, tingkat pendidikan, dan sebagainya, para jurnalis diharapkan agar objektif dan konstruktif dalam penciptaan realitas tersebut agar pembaca dapat terpengaruh ke arah yang konstruktif pula, yakni pelestarian lingkungan hidup dan keluasan pengetahuan mengenai lingkungan hidup.

\section{Daftar Pustaka}

Alexander, Richard \& Arran Stibbe. (2011). From The Analysis of Ecological Discourse to The Ecological Analysis of Discourse. Dalam Language Sciences. Amsterdam: Elsevier.

Allan, Keith \& Kate Burridge. (1991). Euphemism and Dysphemism: Language Used as Shield and Weapon. Oxford: Oxford University Press.

(2006). Forbidden Words: Taboo and The Censoring of Language. Cambridge: Cambridge University Press.
Crystal, David. (2008). A Dictionary of Linguistics and Phonetics. 6th Edition. United Kingdom: Blackwell Publishing.

Fairclough, Norman. (1995). "Critical Discourse Analysis: The Critical Study of Language". London: Longman

Fairclough, Norman \& Ruth Wodak. (1997). Critical Discourse Analysis: An Overview. Dalam Teun A. van Dijk (Ed.), Discourse and Interaction (pp.67-97). London: SAGE Publication.

Fill, Alwin. (1998). Ecolinguistics: State of The Art 1998. Dalam Alwin Fill \& Peter Muhlhausler (Eds.), The Ecolinguistics Reader: Language, Ecology and Environment. London: Continuum.

Fill, Alwin \& Peter Muhlhausler. (2001). "The Ecolinguistic Reader: Language, Ecology and Environment". London: Continuum.

Garner, Bryan A. (2000). The Oxford Dictionary of American Usage and Style. New York: Oxford University Press.

Haugen, Einar. (1972). The ecology of language. Dalam Alwin Fill dan Peter Muhlhausler (Eds.), The Ecolinguistics Reader: Language, Ecology and Environment. London: Continuum.

Khairah, Miftakhul. (2013). Optimalisasi Rekayasa Bahasa: Menuju Media Massa Yang Logis dan Santun. Dalam Risalah Kongres Bahasa Indonesia X. Jakarta: Pengembangan dan 
Pembinaan Bahasa Kementerian Pendidikan dan Kebudayaan.

Kridalaksana, Harimurti. (2008). Kamus Linguistik Edisi Ke-4. Jakarta: Gramedia Pustaka Utama.

Leech, Geoffrey. (1981). Semantics. Great Britain: Pinguin Books.

Stibbe, Arran. (2010). Ecolinguistics And Globalisation. In Nikolas Coupland (ed.), The Blackwell Handbook of Language And Globalisation. London: Blackwell.
Subagyo, P. Ari. (2009). Tiga Pendekatan dalam Analisis Wacana. Widyaparwa, 37 (2), $133-152$.

Wardhaugh, Ronald. (2002). An Introduction to Sociolinguistics. Massachusetts: Blackwell Publishers Inc.

Webster, Merriam. (1997). The Merriam Webster Dictionary. USA: Merriam Webster Inc. 
58|Mabasan, Vol. 7 No. 2, Juli-Desember 2013:47-58 